\title{
Evaluation of oil shale mining heritage in Estonia
}

\author{
K. Metsaots ${ }^{1}$, K. Sepp ${ }^{1} \&$ K. A. Roose ${ }^{2}$ \\ ${ }^{1}$ Institute of Agricultural and Environmental Sciences, \\ Estonian University of Life Sciences, Estonia \\ ${ }^{2}$ Institute of Ecology and Earth Sciences, University of Tartu, Estonia
}

\begin{abstract}
The evaluation of mining heritage and landscapes has been a topic of worldwide importance during the previous decades. Only a few sites are included in the UNESCO World Heritage List, but there are a great many of those that are considered to be restored as recreation and sports areas, connecting industrial and natural features and giving new usages for a site by exploiting ecological and creative landscape design methods. In Estonia, the subject has become important during the previous ten years - refreshing and multifaceted solutions are needed to give a new life to mining landscapes. The aim of this article is to review the restoration history of oil shale mining sites (oil shale being the most important local mineral resource), to exemplify the two most representative developments in Europe, the Nord-Pas de Calais coal mining region in Northern France and the International Building Exhibition Fürst-Pückler-Land in Lower Lusatia, Germany, to introduce existing restoration methods and developments of oil shale mining areas and elucidate future needs and goals.
\end{abstract}

Keywords: industrial landscape, mining history, landscape restoration, restoration methods, recultivation.

\section{Introduction}

In Estonia, oil shale mining has already lasted for more than 90 years and the recultivation of mining sites has lasted around 50 years, but until now, not enough attention has been paid to the question regarding the extent of the landscape observed as whole in the course of reusing mining and industrial landscapes and in the process of technological and biological recultivation. 
Across the whole world, the concept of connecting scientific and ecological principles with different social needs and functions in the process of planning mining landscapes, e.g. multifunctional cultural and recreational landscapes and visually attractive artificial landscapes, has been regarded as a field of study for several decades (Nassauer [1]; Ahern [2]; Hands and Brown [3]). Only a few (over 20) mining landscapes have been entered into the UNESCO World Heritage List as cultural heritage sites as having an outstanding value for the history of humankind, but there is a huge number of those that do not reach this level and landscape restoration and finding new functions remains a local issue. An argument is made for the heterogeneity of landscape, where ecological successions and their networks would support biological diversity, increase the enrichment and vitality of species (Jongman and Pungetti [4]; Lafortessa et al. [5]).

The need for new and multifaceted solutions for restoring oil shale mining landscapes has been an issue in Estonia during the last ten years. Instead of implementing monospecific and monofunctional recultivation projects, it has to be considered that mining landscapes can be used in many different ways: as sports grounds, recreational and tourism areas. Mining landscapes and industrial objects offer good possibilities to implement innovative solutions. Preserving former mining settlements as distinctive milieu-valuable areas can improve local identity and prove to be a tourism attraction. Examples and experiences of other countries can be applied and the need for cooperation is evident.

First, a review of oil shale mining is given. Second, the approach to landscape in the recultivation of mining areas is discussed. Third, what are given are the two most representative European examples of developing mining districts, which are mutually complementary. The Nord Pas de Calais coal mining region in Northern France was chosen for long-lasting connections between district's environmentalists and Estonian University of Life Sciences. The International Building Exhibition Fürst-Pückler-Land in Lower Lusatia, Germany, was chosen due to the region's similarity to the oil shale mining region. In addition, some destinations have also been visited by one of the authors. Following that, the restoration methods and development of oil shale mining areas are introduced and finally, future needs and goals for the holistic growth of oil shale regions are determined and analyzed.

\section{Retrospect view on the history of oil shale mining}

Oil shale is the most important mineral resource in Estonia and among the major oil shale mining countries (Estonia, Russia, China, Brasil, Australia and Germany), Estonia holds the leading position with the highest quantity. It is the basis of Estonia's energy production and chemical industry.

Oil shale is mined in northeast Estonia, in East Viru County from the Estonian mineral deposit. Mining began in 1916 due to fuel deficiency during World War I. In three years, two mining districts developed - Kohtla and Ubja. Thanks to the superior quality of its material Kohtla developed into a district centre. Mining began by open-pit mining. Later, underground mining began. At 
first, oil shale was only mined for the oil industry. Independent mines did not come into being until the occurrence of state capitalism with centralized leading (from 1940 in the German and from 1944 in the Russian system). State capitalism is dominant to this day. The mining plants of oil shale processing factories started work again as late as in the beginning of the $21^{\text {st }}$ century in Kiviõli and Ubja.

Production increased consistently and culminated with 30 million tonnes in 1980 in connection with launch of two large power plants - the Baltic thermal power station in 1965 and the Estonian thermal power station in 1973. Import decreased and mining capacities started to diminish when in 1981, a nuclear power plant was put into operation in Sosnovy Bor in the former Soviet region Leningrad (Kattai [6]; Reinsalu [7]).

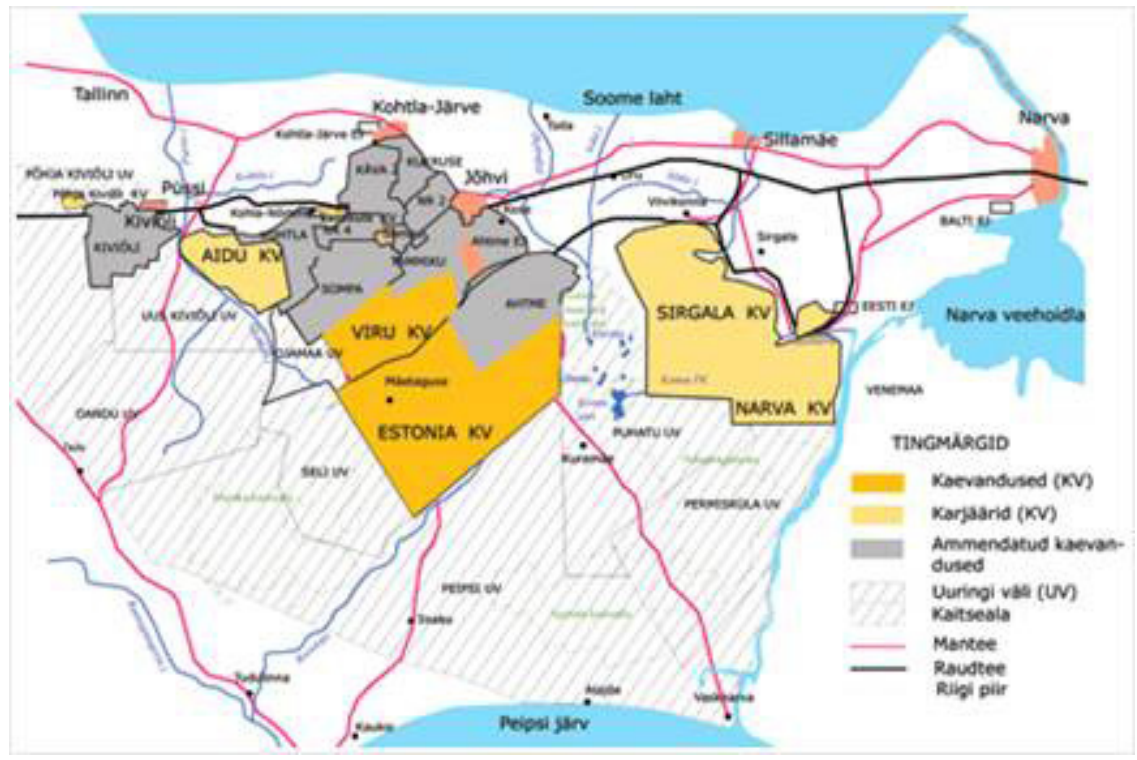

Figure 1: Oil shale mining areas of the Estonian deposit (Eesti Põlevkivi 2008). Dark yellow - mines, light yellow - quarries, grey excavated mines. (See online for colour version.)

Today, mining produces 15 million tonnes of oil shale per year. The amount of active resources reaches 1.1 billion tonnes, which is more than has been marketed during the 90 years of mining. Both underground mining and opencast excavation are used, up to the depth of 70 and 30 meters, accordingly (Sokman [8]). Landscape changes derived from opencast mining form $0.3 \%$ and land influenced by underground mining makes up $0.6 \%$ of the state's territory. Pro tempore, 20 mining sites, quarries and mines are still are in operation or used to extract oil shale. The largest in Estonia as well as the world is the Estonia Mine (Reinsalu [7]). 
The landscape features common in northeast Estonia are limestone hills formed from wall rock, leftovers from the process of oil shale beneficiation (33 pieces), industrial semi-coke hills, so called terricones (6 pieces), vast dumps, thermal power plant ash plateaus (over $2000 \mathrm{ha}$ ), underground mining collapse areas (around 106 ha) (Kaar [9, 10]; Sokman [11]).

\section{Approach to landscape in recultivation}

Recultivation methods and finding new functions for excavated areas have been written about and discussed in Estonia for longer than half a century. In the 1960s and 1970s scientific articles were published, normatives and principles were developed, but landscape approach in the process of recultivation was put into practice in only a few cases and thanks to the initiative of enthusiasts. In the 1990 s, policies related to the protection of rural, natural and cultural values, the holistic landscape approach was not considered either. Landscape use, protection and design issues were rather undetermined outside the protected areas. So, until recent years, the evaluation of industrial and mining landscapes has been absent. Now, policies are changing - for example, the national nature conservation development plan until 2035 assigns that construction heritage (including industrial and mining heritage) shall be a significant part of valuable Estonian landscapes and without its valuation, it will not possible to fulfil the goals of landscape protection and management.

One of the reasons why landscape approach had so far only remained on the theoretical level is the fact that landscape architecture had not found its place in the field of professional education and had not been able to validate itself in the hierarchy of engineering. Legally, there were no landscape architects and landscape objects were not treated as they, too, belonged in the sphere of architecture (Sepp et al. [12]).

\section{Nord-Pas de Calais coal mining region in Northern France}

In Nord-Pas de Calais, the coal was mined in the coal basin for 270 years, from 1720 to 1990 . The basin is around $120 \mathrm{~km}$ long and $12 \mathrm{~km}$ wide. Some 1.2 million inhabitants live in the region. The mining industry's decline was followed by an economical and social depression. About 40 years ago, were started to find applications for industrial heritage and solutions for socioeconomic problems. At the end of the 1960s and in the beginning of the 1970s, administrative leaders attempted to determine how to associate urbanization and the utilization of industrial heritage.

It was decided to establish polyfunctional centres into dormitory-type mining settlements, renovate buildings that had belonged to coal miners and give them a new use or, if needed, demolish them. Mining settlements were to be connected with towns in terms of their administration, function and development.

Wall rock hills were a specific problem - it was impossible to avoid them and no simple solution existed for them. They only caused contradictions and conflicts. At first, they were considered to be disturbing eyesores in the 
landscape - negative monuments of the past. Above all, the value of production was seen - with a second sorting, it was possible to get more coal. Many of the hills were indeed liquidated by additional sorting, and some were hidden by planting high vegetation on them. Later, the wall rock heaps were used in creating green areas, either for ecological value or simply as potential green sites, which are scarce in the region. For natural scientists, a wall rock heap served as a field laboratory, where they could observe the distribution and interspecies relations of plants and animals in a unique milieu. By now, over 40 wall rock heaps have been counted in natural areas of ecological, fauntistic and floristic value (Zones d'Intérêt Ecologique, Faunistique et Flostique, ZNIEFF). The recognition of wall rock heaps as an introduction and representation of cultural and historical heritage is a phenomenon prevalent only in the previous decades. The region is also a great playground for development activities. In addition, the heaps are rooted in the regional identity and image of the area as positive landmarks. The triangular motive of a wall rock heap is a famous symbol of the Nord-Pas de Calais region. The motif has also been dignified in the logos of several institutions and administrative units.

The last decades have seen the birth of several new institutions, which are engaged in the valuation and implementation of mining heritage. Etablissement Public Foncier, the so-called Public Land Agency, whose main task is to regulate industrial landscapes, was established in 1990. The Agency renovates real estate associated with mining and recultivates wall rock heaps, liquidates residual pollution, compiles environmental surveys and takes inventories of industrial heritage. In the last years, collaboration has been the keyword.

In 2000, representatives from governments on state, regional and local levels decided to join their forces to create better possibilities for economical, environmental, urban and social development in the coal basin. To achieve those aims, the Coalfield Land-Planning Agency (La Mission Bassin Minier) was established. Above all, efforts are being made to help local governments solve problems originating from coal mining (polluted soil and water, spoilt landscapes, socio-economic problems, extension of mining settlements' functions etc) and promote landscape planning and the development of region. As many different parties as possible have been involved in development activities. Great attention is paid to the local community's preferences. The actions of the Coalfield Land-Planning Agency are based on a development plan accepted by each party. Before the plan was accepted, the whole mining region was evaluated and zoned. Every wall rock heap, mining settlement, building complex was approached individually. The global aim is the inclusion of the Nord-Pas de Calais region into the UNESCO cultural heritage list.

The most successful and well-known project in the region is the recultivation of the Rieulay' wall rock heap. This area of 140 hectares was designed to hold an attractive water body (for swimming and water sports, windsurfing, canoeing, rowing), a sandy beach, a football field, walking paths, a mountain bike path, fishing ponds, wetlands, unique habitats for amphibians and Mediterranean plants, closed areas for birdnests, a Mediterranean orchard etc (Maran [13]). 


\section{Mining landscape restoration example from Germany: IBA Fürst-Pückler-Land 2000-2010}

The organization of construction exhibition projects in Germany started as early as in the middle of the $19^{\text {th }}$ century. The first international independent construction exhibition took place in the year 1901 in Mathildenhöhe, Darmstadt. At first, it was about presenting contemporary urban architecture, but IBA (Internationale Bauausstellung) Berlin 1984-1987 brought along a new focus point - urban renewal and new forms of planning. IBA Emscher Park 1989-1999 focussed on a holistic approach for the whole region. The ecological issues raised were developed further at IBA Fürst-Pückler-Land 2000-2010.

Lusatia is a German region regarded to be the most affected by human activity. In addition to causing landscape changes, 150 years of lignite mining have strongly influenced the settlement and its infrastructure, culture and population. During the period of industrial prosperity, population inflow occurred, but at the same time, some 80 towns and villages remained on the way of mining and their inhabitants were forced to migrate. By now, thousands of people have left the district due to unemployment.

Mining companies have a legitimate obligation to restore used areas. In the case of East Germany's liquidated state enterprises, the task remained in the hands of the government of the reunited Germany. Before the IBA, three scenarios for the renewal of landscape had been introduced to the agenda.

Scenario 1. Redemption through restoration: revegetation and overdevelopment, removing all unused industrial objects from the landscape. The mining heritage would disappear from sight and a distinctive lake region would be developed.

Scenario 2. No innovations. After stopping water pumps, the landscape would be allowed to self-evolve. The result would be a spontaneously evolving and unique nature protection area.

Scenario 3. Economizing on overdevelopment. As the consequences of industrial activities are overwhelmingly difficult on nature's self-improving power, the area must be restored by humans. Water inflow to quarries would be regulated and a suitable inclination would be given to slopes. The region's industrial past cannot be deleted, but outstanding architectural and topographical elements and shapes must be retained as the industrial heritage of district - such historical evidences, after all, give the area its uniqueness.

The third scenario was chosen by IBA. The main principle was to combine old with new, preserve regional identity, underline refreshing fantasies and high design standards in new developments. As a limited liability company with an appointed time of operation, IBA serves as a mediator and does not participate in planning processes - i.e. it does not compile development plans and does not possess planning rights or institutional power. Instead, its task is to suggest and initiate projects, bring together different parties and guide structural changes.

At first, 20 projects were launched, but eventually, 30 evolved out of the initial ones. Projects are divided into nine: the centre, seven landscape islands and the island of Europe. The islands are areas with very different conditions, 


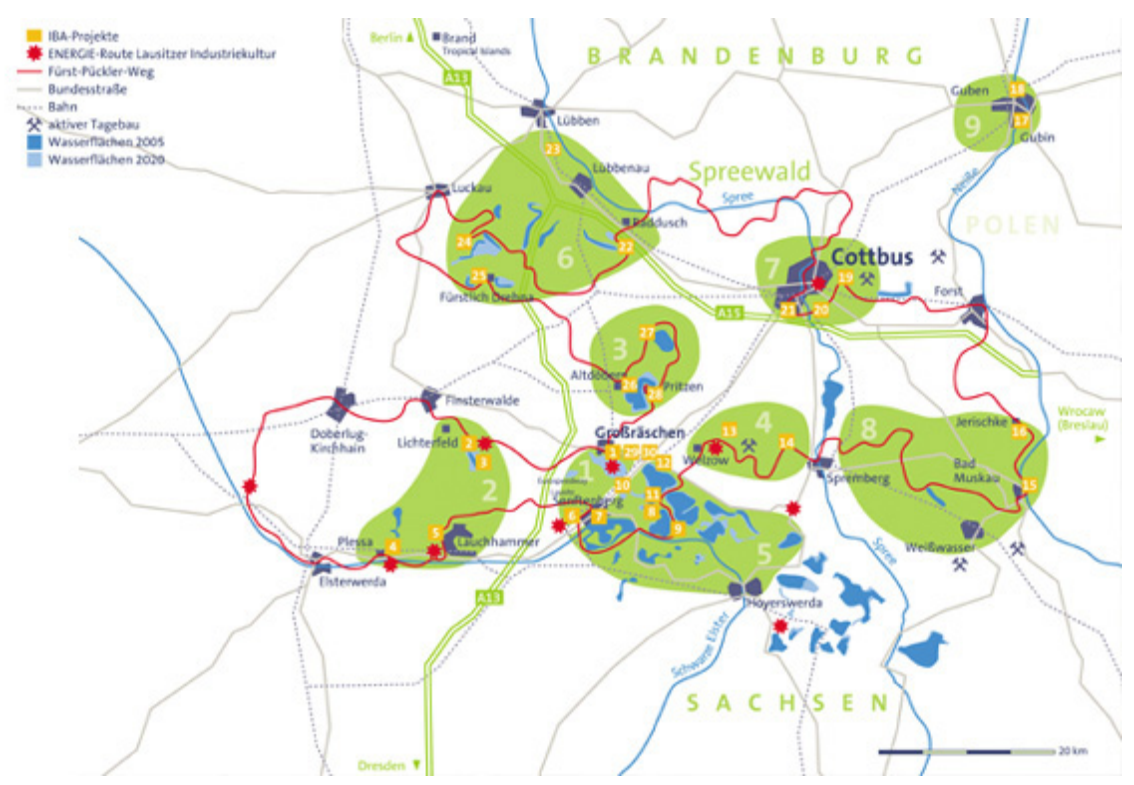

Figure 2: Network system of IBA Fürst-Pückler-Land. Green - islands, yellow numbers - project areas, red line - energy route of industrial heritage. (See online for colour version.)

structure and problems, each having its own focal point. For example, landscape island Industrial Heritage introduces distinctive industrial monuments: the mining heritage landscape of excavator F60, Lauchhammer bio-towers, the power plant Plessa. Landscape islands are bound together by network and connections, among them Energy Route and the bicycle route Fürst Pückler Path.

Six EU projects have been accomplished or still in operation. REKULA (2000-2006) was a project for restructuring cultural landscapes with three partners: Lower Lusatia in Germany, Upper Silesia in Poland and Veneto in Italy. The main aspect was the improvement of living conditions by adapting very specific remedies. VIKTOUR (Virtueller Industri-Kultur-Tourismus, 20022005) and IdeQua (2004-2006) were directed at tourism development. IdeQua collaborated with 17 international partners from six countries and its main purpose was to strengthen regional identity. The sustainable forestry management project RW (Robinwood, 2006-2007) had partners from Italy, Britain, Spain and Slovakia. In Lusatia, fast-growing trees were planted on a mining site to demonstrate the potential of biomass production. RenERg EuReg (Renewable Energy Resources - a Solution for the Sustainable Development of Two European Regions, 2008-2010) was a bi-national (Lusatia and Romania's Region Centru) project for innovative energy strategies. ReSOURCE (20092012) is an initiative for small to medium-sized regions in central Europe, where mining is being slowed down or has already stopped. The aim is to highlight the potential opportunities created by the legacy of mining. All projects are 
transnational and forming a cooperation network is inherent to them. Outside the EU, IBA is involved in projects in the Atacama Desert in Chile and Nizhny Tagil in Russia.

A ten-year period was divided into two. In the second stage, since 2006, the goals have been a greater connection between projects and increasing the awareness of people and decision-makers about ongoing changes. Every year saw the introduction of a new issue: 2006 - New Europe, 2007 - New Energy, 2008 - New Water, 2009 - New Land. The year 2010 was dedicated to summarizing outcomes and ending the organisation of the exhibition, but projects will nevertheless be developed further in the future. The final prospective outcome is a region of new landscapes with awakened tourism and functional enterprises (SEE [14]).

\section{Restoration of mining areas in Estonia}

The attitude that Estonian people have towards landscape is closely related to their selective valuation of the past. Manor and farm landscapes are considered to be most essential and heritage of the recent past is almost left unconsidered, may it be ecologically developed ameliorative projects or mining heritage. Estonians appreciate diverse and patriotically beautiful landscapes with a long history and tourism value. As Estonian landscapes are only looked after on protected areas, then the arrangement and development conditions regarding common landscapes (industrial, urban, rural and others) are established in planning acts. The value of a landscape is often contributed to developments carried out in the area.

That kind on contrasting landscape management limits the diversity of Estonian landscapes and their environmental quality. Landscape management must not be restricted to valuable areas, but also cover the more common and typical industrial, rural, urban and rustic landscapes, damaged areas among them (Palang et al. [15]; Parts [16]). During the last few years, the direction has been towards the valuation of common landscapes, including industrial ones. The national nature conservation development plan until 2035 emphasizes that construction heritage (including industrial and mining heritage) is an important part of valuable Estonian landscapes and without preserving them, it is impossible to fulfil the goals of landscape protection and management. Construction heritage and heritage landscapes, though, have not been taken into account so far and no conditions and restrictions have been validated for their protection.

Still, the appreciation and forming of Estonian mining district landscapes were not begun from scratch. Beautiful and distinctive landscapes were designed in Soviet times by the initiative of enthusiasts. Several examples can also be given from the past few years. A concentrated list of examples of best usage of oil shale mining and production areas has been prepared. 


\subsection{Recreational landscapes}

\subsubsection{Vesiloo landscape of lakes}

The first example of planned landscape diversity is the Vesiloo lake (18 ha) in Viivikonna Quarry, established in the 1970s. The lake inherited its name from Paul Vesiloo, the founder of the lake and head engineer of Viivikonna Quarry. In addition, there are President's Lake, Kenajärv Lake and some smaller artificial lakes in Sirgala and Viivikonna quarries, used by locals for recreational activities and swimming, but also for fishing.

\subsubsection{Kohtla Mine Park Museum}

The Kohtla mining museum is the best example of what can be done with a closed mine and its territory and buildings. The site was reclaimed and afforested in 1986. In 2000, after long discussions and negotiations, the decision was made to create a mine park.

Mountain skiing slopes and slanting slopes for beginners were created on wall rock heaps and dumps. Bicycle trails and ATV roads, a steady roller skiing path, a climbing wall on enrichment factory's wall and many more exciting objects and facilities were built. A training complex and the museum's exposition are being developed. During its six years of operation, the museum has been visited by 176,000 people.

\subsubsection{Kiviõli old ash mountain}

Old semi-coke hills with an enormous amount of waste are one of the most important and complicated environmental problems in whole of East-Viru County. They must be brought to a condition as environmentally harmless as possible with optimized expenses (Kattai [17]).

Kiviõli old semi-coke hill (absolute height $141.84 \mathrm{~m}$, relative height $93 \mathrm{~m}$ ), to which 6.3 tonnes of semi-coke and bottom ash were transported in 1922-1967, is being developed into a recreational centre of national importance (Pae et al. [18]). Numerous surveys, environmental impact assessment, detailed plans and preliminary projects for motor complex and adventure tourism are being prepared. In 2006, the construction of a motor complex was launched and at the same time, an additional survey of thermal processes was carried out (Kiviõli Seiklusturismi Keskus [19]).

According to a detailed plan, mountain skiing and slalom slopes, a trail for snow boarding and snow tubing, a half-pipe snowboard chute, a sled riding hill, uphill tracks for motorcycles and motocross tracks are being conceptualized (Kiviõli vana poolkoksimäe maa-ala detailplaneering [20]). Construction areas, an event-organizing site, a camping site, cross trails, parking and traffic areas are planned to be built to the foot of the hill and land mark to the top of the hill. The tracks and facilities will be completed in several stages.

Since 2003, international motorcycle uphill raising competitions have been taking place on the mountain annually. In 2007, the Qualda cross-country show also occurred: at the North-Estonian tourism conference, it was chosen as the year's best tourist event. One of the goals of the show was to obtain permission from the International Motorcycle Federation (FIM) to arrange international 
motoring competitions on the hill in the future. In 2008, a stage in the cyclecar world championships and a stage in the quad racer European championships were held there.

\subsubsection{Kukruse wall rock dump}

Relative height $41 \mathrm{~m}$, stored in 1955-1967, volume $710,000 \mathrm{~m}^{3}$, self-ignition process with certain environmental dangers is continuing (temperature on the ground $50^{\circ} \mathrm{C}$ ). Thanks to its advantageous location next to the Tallinn-Narva highway, the hill is one of the most popular tourism objects in East-Viru County. A panoramic view of oil shale landscapes opens to the town of Kohtla-Järve in the west, Jõhvi City in the south, to the Gulf of Finland in the north and to Kukruse Village from the front. The Kukruse uphill race is evolving into a tradition.

\subsubsection{Tammiku wall rock dumps}

The complex consists of three dumps with the height of 12, 20 and 40 meters and with a total area of about 35 ha. The highest one is built on three terraces, which were afforested in 1973 and 1975. In autumn 2007, landscape architecture students from the Estonian University of Life Sciences, in collaboration with the representatives from the local government of Jõhvi Parish, composed landscape development visions for the utilization of the Tammiku wall rock dump.

One of the more interesting works was titled "Tammiku paths", which intends to present the dump from different viewpoints. The idea includes three different journeys named history path, activity path and beauty path. The first two are more specific, the third one more abstract. The history path introduces the origin of dumps and the events connected to oil shale mining. It is a narrow-gauge railway line running on slopes and crests with a mining train with a score of passengers travelling through the exposition. Activity paths are most pragmatic. They consist of connection tracks with strategic points of interest - a concert place, the centre, sled riding slopes, protected forests, watchtowers, a lake and swimming spots, boardwalks, parking areas, a park. The surrounding bicycle, skating and roller-skiing tracks are also interpreted as activity paths, connecting the area to neighbourhood settlements. The beauty path is joined together ideologically, without concrete navigation instructions. It takes advantage of mountain districts, to which the visitor is not guided by other paths, but where panoramic views offer a chance to enjoy the surroundings or which are themselves seen from the distance.

\subsection{Military landscapes}

Since the 1990s, landscapes of Sirgala Quarry have been used for military training. The Estonian Ministry of Defence is planning to establish a defence forces rehearsal field in the forests of Sirgala Quarry. For the purpose, the intended purpose of land usage has to be changed from profit land to national defence land. In planning military areas, afforestation is put aside and the landscape will be enriched with new elements - steeps, hollows, water bodies. 
Drowning former transport trenches is also foreseen. According to development plans, it will happen around the year 2025 .

\subsection{Town landscapes}

\subsubsection{Town parks}

In the course of the expansion of towns, older quarries remained into urban spaces. A good example is the Pavandu Quarry, which has become a fully fledged town park in Kohtla-Järve. In the 1970s, town parks were established especially numerously. The demolition of mining workers' barracks and the creation of town parks was connected to the validation of sanitary zones between the industrial zone and the dwelling area of Kohtla-Järve (52 ha of green areas in the district of Järve City) and Kiviõli (56 ha of maintained green areas). Likewise, it was s decisive period in building new multi-storey house districts, enabling to empty barrack districts.

Allotments belonging to barracks and high vegetation, mainly apple trees, but also avenues bordering streets, created the preconditions for and simplified the creation of several dozen hectares worth of town parks, serving as a green belt around the territories of chemical industry. In high vegetation poplars dominate, with their ample flowering inducing annoyances to allergics and maintenance service, thus need to be replaced, also for their age and breaking danger.

\subsubsection{Industrial parks}

Former quarries, mine buildings and constructions can be exploited for enterprise development. For example, an industrial park has been in development on the territory of a former mining training centre in the western part of Jõhvi City since 2003. Largely useless constructions have been dismantled and new infrastructure created. At the moment, ten enterprises are operating on the 25 hectares of the industrial park.

\subsection{Rural landscapes}

\subsubsection{Recultivation plan for Vanaküla Quarry}

In 1993-1994, engineers from an environmental engineering company from Great Britain called Richards, Moorehead \& Laing Ltd, composed a restoration model project for the landscapes spoilt by the oil shale quarry (Richards, Moorehead \& Laing Ltd and AS Eesti Põlevkivi [21]). The project was partly accomplished in the overground part of the Vanaküla Quarry in the Kohtla mine. The aim of the model plan was to develop a restoration technology for diverse land use. It was determined to divide the excavated areas into different plots for forestland, meadowland and arable land, while considering the interests of farmers. The planned landform was meant to merge into the surrounding landscape and excessively steep slopes were not allowed. Unlike the typically monotonous solutions of these times, the mining field was divided into smaller parcels with different shapes, forms and purposes. a slightly undulating area was planned, with an overall inclination to south. The northern borders of cadastral units were edged with hedges. 


\section{Public expectations regarding restoration and the utilization of mining landscapes}

People's awareness about landscape values varies greatly and is often inclined. Without being familiar with landscape history, a consensual protection of landscape heritage is impossible - landscape related professional education and training landscape management specialists must be fostered. The vision of local people in terms of valuable landscapes, including industrial ones, must be examined and their characteristics, dynamics and transforming influences must be analyzed (Palang et al. [15]).

According to common public expectations, at least an equivalent value must be achieved with restoration, compared to the condition of the landscape before mining. In addition, greater attention needs to be paid to the interests of local governments and the district's inhabitants, and supervision is expected to be more effective. Large mining areas are assumed to find a purposeful usage. There is a continuous suspicion that data about the land use of mined areas is imprecise, control over the size and condition of unused and spoilt areas is lacking and thus, land use is not at all guided according to the expectations of the public (Saar Poll [22]). Environmental responsibility is not always definite and the owner's obligations are not always fulfilled. It is presumed that prognoses for the future needs and usage programmes regarding mineral resources are insufficient; that mining, landscape, water and nature protection needs are not compatible, be it on state level or the level of local governments; that interest for restoration of unclaimed quarries is absent, that recultivation does not serve peoples' needs and is often done poorly; that oil shale wall rock heaps pollute air and water; that mining enterprises do not have a clear solution for surface water and groundwater regime formation after mining activities (Põlevkivi kasutamise riiklik arengukava [23]). Landscape design and architecture methods have often been retracted before they have been overridden because of routine environmental requirements or upstaged because of financial reasons.

To fulfil public expectations, the best environmental practices must be applied, experiences from other countries must be taken into consideration, and dealing with products, buildings, constructions, planning acts and other environmental issues must be completed starting from the initial idea until the final solution. In addition to technological means, image-building must be dealt with; the public must be more informed about the reuse of mined areas and the potential environmental impacts after mining. Including local governments and civil initiative organisations into planning for mined areas has so far been quite random.

\section{Conclusion}

The issue of landscaping in terms of the recultivation of areas and giving new functions to excavated areas has been written about and discussed in Estonia longer than half a century, but until now, only a few restoration projects have considered to have landscape architectural and ecological approach. Legislation 
demands that recultivation was conducted for the purposes determined in the mining permission. Even though regulation and normatives for restoring mined areas are sound from legal viewpoints as well as punctual and strict from engineering viewpoints, a landscape-centred approach is completely absent and an ecological approach is vague. What is needed above all is that criteria for landscaping and biological diversification were added to recultivation normatives, as landscapes and biological diversity reproduce each other.

Industrial landscapes in northeast Estonia must not be recultivated in a way that does not leave any traces of their industrial past, for the artificial mountains create variability to the plain landscapes of northern Estonia. Attitudes towards wall rock heaps, dumps, industrial complexes must be reassessed and a new function must be given to them. Wall rock heaps and quarries would be most suitable for large-scale recreation areas, parks, hiking trails, theme parks and for adventure tourism. Still, there cannot be several attraction centres of the same type: it has been proven in Europe that in the context of restoring industrial lands into recreation areas, this kind of an approach does not work (Hospers [24]). In carrying out innovative ideas, it must be taken into account that designing new landscapes is limited by several circumstances: manoeuvring abilities of mining vehicles is restricted, the characteristics of surrounding areas must be considered, and new landforms must be fit for their function. Architecturally valuable buildings and unique industrial facilities must be preserved and exhibited.

Until now, criticism of planning practices has referred to the prevention of post-mining impacts by implementing suitable mining technologies and to prolonged and large-scale planning of restoration works (TTÜ Mäeinstituut [26]). Planning should cover more than one mining department. The large-scale approach enables to enrich the post-mining landscapes holistically, providing different functions and a landscape design appropriate for an artificial landform. Thematic plans should be prepared. After the approval of a national development plan for oil shale mines, the establishment of a coordinative body should be seriously considered. The body would connect parties, join the management of different sectors, solve conflicts between public and private interests. The simplest solution would be to arrange international competitions for landscape architects. Support would be obtained from cooperation with the EU and from the Structural Fund. Without domestic and transnational cooperation, it is difficult to ensure an economical re-use of mining districts. There are many great examples of developing mining regions in Europe. In this article, the experiences of France and Germany were discussed.

Oil shale mining will continue for at least 20 more years. It allows designing landscape and storing wall rock already during mining works, and apart from the recultivation of quarries, finding opportunities to develop the region's identity and promote its positive image by implementing innovative landscape design. According to a public survey, the best new function for each area should be investigated in areas where mining has ended. The interests of local inhabitants have great importance and it must be expressed in the holistic vision, which retains, improves and develops the industrial and mining heritage of East-Viru County. 


\section{References}

[1] Nassauer, J. I., Culture and changing landscape structure. Landscape Ecology, 10(4), pp. 229-237, 1995.

[2] Ahern, J., Spatial concepts, planning strategies and future scenarios: a framework method for integrating landscape ecology and landscape planning. Landscape Ecological Analysis: Issues and Applications, ed. Klopatec, J., Gardner, R., New York: Springler-Verlag, pp. 175-201, 1999.

[3] Hands, D.E. Brown, R.D., Enhancing visual preference of ecological rehabilitation sites. Landscape and Urban Planning, pp. 58, 57-70, 2002.

[4] Jongman, R. and Pungetti, G., Ecological networks and greenways: concept, design, implementation. Cambridge University Press, 345 pp., 2004.

[5] Lafortezza, R., Sanesi, G., Pace, B., Corry, R.C., Brown, R.D., Planning for the rehabilitation of brownfield sites: a landscape ecological perspective. Brownfield Sites. Assessment, Rehabilitation and Development, ed. Donati, A., Rossi, C., Brebbia, C.A., W.I.T. Press, Southampton, UK, pp. 21-30, 2004.

[6] Kattai, V., Eesti põlevkivi: geoloogia, ressurss, kaevandamistingimused. Akadeemia Trükk, pp. 4-6, 2000.

[7] Reinsalu, E., Põlevkivi ja selle kasutamine. Maavarade kaevandamine ja puistangute rekultiveerimine Eestis, ed. Kaar, E., Kiviste, K., Ecoprint, Tartu, pp. 7-14, 2010.

[8] Sokman, K., Maavarade kaevandamise mõju maakasutusele. Maavarade kaevandamine ja puistangute rekultiveerimine Eestis, ed. Kaar, E., Kiviste, K., Ecoprint, Tartu, pp. 56-69, 2010.

[9] Kaar, E., Aherainemägede taimestumine ja haljastamine. Maavarade kaevandamine ja puistangute rekultiveerimine Eestis, ed. Kaar, E., Kiviste, K., Ecoprint, Tartu, pp. 301-320, 2010.

[10] Kaar, E., Soojuselektrijaamade tuhaväljade taimestamine. Maavarade kaevandamine ja puistangute rekultiveerimine Eestis, ed. Kaar, E., Kiviste, K., Ecoprint, Tartu, pp. 361-384, 2010.

[11] Sokman, K., Paemäed, aheraine omadused ja kasutamine. Paekonverentsi kogumik, Kohtla-Nõmme, pp. 7-9, 2004.

[12] Sepp, K., Metsaots, K., Roose, A., Kaevandamisega muudetud maastike väärtustamine ja kujundamine. Maavarade kaevandamine ja puistangute rekultiveerimine Eestis, ed. Kaar, E., Kiviste, K., Ecoprint, Tartu, pp. 105$128,2010$.

[13] Maran, M., Kaevandusala rekultiveerimise analüüs Rieulay (PõhjaPrantsusmaa) näitel. Bachelor's thesis on landscape architecture in Estonian University of Life Sciences, 2005.

[14] SEE. IBA-Werkschau, Bewegtes Land, IBA-Halbzeitdokumentation 2000-2010. Wolf, K. (ed.), INPETHO® Medienproduktion GmbH, 2005.

[15] Palang, H., Sepp, K., Sooväli, H., Eesti maastikupärand ja selle hoidmise võimalused. Eesti jätkusuutliku arengu teel, ed. Punning, J.-M., Tallinn: Eesti Entsüklopeediakirjastus, pp. 75-83, 2006. 
[16] Parts, P-K., Kultuurilise tootmise tehnoloogia poole: kultuuripärandi näide. Akadeemia, 2, pp. 227-271, 2007.

[17] Kattai, V. Põlevkivi - õlikivi. Tallinn, Eesti Geoloogiakeskus, 2003.

[18] Pae, T., Luud, A., Sepp, M., Mis on Eesti kõrgeim tehismägi? Eesti Loodus, 5, pp. 18-20, 2005

[19] Kiviõli Seiklusturismi Keskus http://www.tuhamagi.ee/ 20.02.2011

[20] Kiviõli vana poolkoksimäe maa-ala detailplaneering. K\&H AS, 2004.

[21] Richards, Moorehead \& Laing Ltd, AS Eesti Põlevkivi, Kaevandamise ja taastamise arengukava Kohtla pealmaakaevandusele,1996.

[22] Saar Poll. Ida-Virumaa põlevkivitööstusse suhtumise uuringu aruanne. 2006.

[23] Põlevkivi kasutamise riiklik arengukava 2008-2015. Riigikogu seaduse eelnõu. Keskkonnaministeerium, 2008.

[24] Hospers, G-J. Industrial heritage tourism and regional restructuring in the European Union. European Planning Studies 10 (3), pp. 397-404, 2002.

[25] TTÜ Mäeinstituut. Teadustöö aruanne Põlevkivi Kaevandamise AS ettevõtete tööst tulenevate hüdrogeoloogiliste muutuste prognoosi koostamine, 2004. 